\title{
ANTARA AGAMA DAN BISNIS \\ BISNIS DALAM PANDANGAN ISLAM
}

\author{
M. Zikwan \\ ziksaririzik@gmail.com \\ Universitas Ibrahimy Situbondo
}

\begin{abstract}
ABSTRAKC
Business is an effort made by someone or more to make ends meet through production activities, or buying and selling of products. Some circles say that business is an activity to make as much profit as possible, so religion cannot be combined with business. Islam is not an anti-business religion but Islam is a religion that regulates business activities. The spirit of Islamic business is Islam, Iman and Ihsan. The principles of business in Islam are the principles of Illahiyah, the principles of Nubuwwah, the principles of al-Adaliyyah, the principles of al-Hurriyah, the principles of al-Musawwah, the principles of Ta'awun. Islam is not a religion that prohibits business, but Islam is a religion that supports business activities. Prophet Muhammad as the bearer of the message of Islam, including business people, more than that the Prophet Muhammad was the pioneer of business in Islam. Islam has never prohibited the ummah from doing business, even Islam gives the value of freedom in doing business activities.
\end{abstract}

Key word: Agama, Bisnis

\section{PENDAHULUAN}

Akhir-akhir ini kajian sepetar bisnis seringkali menjadi tajuk utama pembicaraan masyarakat baik masyarakat kelas ekonomi menengah maupun masyarakat yang baru hendak memulai bisnisnya, menjadi perbincangan baik dilingkungan para intelektual maupun kalang awam. Hingga akhirnya perbincangan bisnispun tidak bisa dihindarkan disetiap kalangan baik sekala mikro maupun makro. Pada era saat ini siapanpun bisa melakukan aktivitas bisnis, mulai dari anak usia sekolah dasar, remaja, dewasa maupun kalangangan orang tua. Hal ini dikarenakan aktivitas bisnis menjadi hal yang mudah dan menjanjikan untuk memenuhi kebutuhan hidup sehari-hari. Dari praktek bisnis yang dilakukan oleh setiap kalangan banyak yang menuai kesuksesan, namun tak jarang juga yang mengalami vailid atau mengalami kerugian.

Dalam beberapa kajian ekonomi, bisnis seringkali diartikan upaya yang yang dilakukan sesosorang atau organisasi untuk menjual barang atau jasa kepada konsumen atau pembisnis lainnya dengan tujuan untuk memperoleh laba. Jika dilihat secara tektualis historis, kata bisnis berasal dari bahasa inggris business, jika kembali kepada akar kata business maka akan menemukan kata busy yang artinya "sibuk" dalam pengertian sibuk 
dengan aktivitas-aktivitas yang dapat menghasilkan laba. Dalam pandangan kapitalis bisnis seringkali dilakukan oleh pihak swasta dibentuk untuk mendapatkan laba yang sebesar-besarnya untuk meningkatkan kemakmuran pemilik atau kelompok bisnisnya. Namun, secara sederhana bisnis dapat diartikan sebagai kegiatan yang dilakukan oleh seseorang atau lebih yang telah terorganisasi dalam mencari laba dengan cara menyediakan beberapa produk yang dibutuhkan oleh konsumen atau masyarakat (Dr. Francis Tantri, 2009). Salah soerang peneliti Amerika George W. England melakukan penelitian kepada 1.072 manager perusahaan di amerika, terdapat beragam pendapat yang diperoleh tentang tujuan perusahaan/bisnis, namun pada akhirnya George W england memilih 5 tujuan yang hendak dicapai dari perusahaan atau dari kegiatan bisnis perusahaan yaitu; Protability, Produktivity, Growth, Employee, Community Interest.

Hingga saat ini perkembangan dunia bisnis semakin pesat, tidak hanya dipusat perkotaan saja, perkembangan bisnis juga sudah sampai kepelosok desa. Namun dalam perjalanan bisnis seringkali masyarakat atau pelaku bisnis memisahkan antara agama dan aktivitas bisnis. Pada dasarnya Islam hadir dimuka bumi ini dalam rangka mengatur seluruh aktivitas yang ada didunia ini, mulai dari aktivitas ibadah (hablm min Allah) sampai pada aktivitas mu'amalah (hablm min an-nas).

Berkaitan hubungan agama dengan bisnis, bahwa sejak terbitnya buku The Protestant Ethic and The Spirit of Capitalism 1904 Weber sangat berjasa untuk membuktikan hubungan agama dengan kegiatan perekonomian (bisnis), masyarakat yakin adanya hubungan erat antara agama dan kerja atau agama dengan kemajuan ekonomi. Jika weber saja memiliki analisis yang kuat terhadap hubungan bisnis dan agama, maka semua agama pasti memiliki keyakinan yang tidak jauh berbeda.

Tidak ada manusia yang hidup didunia ini tanpa agama, karena agama merupakan pedoman bagi setiap pemeluknya. Diantara agama yang banyak dianut oleh manusia atau masyarakat adalah agama Islam. Islam bagi penganutnya adalah agama yang syumuliyah (sempurna). Ajaran Islam yang Syamil Muktamil (sempurna menyeluruh) memberikan pemahaman yang mendalam, bahwa Islam tidak hanya hadir dalam waktu yang singkat, ia merupakan agama sepanjang masa. Dalam ajaran Islam tidak hanya mengatur hubungan seoarang makhluk dengan khaliq saja, namun jauh daripada itu Islam mengatur eksistensi manusia dimuka bumi ini. Oleh karena itu Islam seringkali disebut sebagai pedoman hidup way of life ( Eko Suprayitno, 2005) karena ajaran Islam bersifat 
komprehensif dan universal. Makna komprensif berarti agama Islam mengatur semua aspek baik berupa ritusl (habl min Allah) maupun hubungan sosial (habl min an-nas). Sedanga universal berarti Islam dapat diterapkan dalam setiap waktu dan tempat dan hidup sepanjang masa. Sehingga Islam mengatur semua aktivitas manusia mulai dari halhal yang kecil sampai kepada persoalan yang besar.

Negara Indonesia termasuk negara pemeluk agama Islam terbesar didunia, akan tetapi negara Indonesia tidak bisa dikatakan sebagai negara Islam yang menganut faham khilafah, karena negara Indonesia berdiri diatas asas pancasila. Akantetapi falsafah pancasila juga selaras dengan ajaran Islam. Sebagai negara penduduk muslim mayoritas, aktivitas masyarakat Indonesia selalu didasari atas ajaran Islam, mulai dari kegiatan transaksi sampai kepada urusan politik dan tata negara. Namun dalam dekade terakhir ini, seringkali muncul persoalan-persoalan tentang hubungan antara agama (Islam) dengan kegiatan bisnis. Sebagian kelompok mengantakan bahwa agama dan bisnis adalah sesuatu yang berbeda, kelopok yang laini ada yang berpendapat bahwa agama dan bisnis adalah satu kesatuan yang tidak bisa terpisahkan. Oleh karena itu penulis ingin memberikan ulasan singkat antara keterkaitan antara agama dan bisnis dengan tujuan untuk menarasikan hubungan Islam dalam bisnis.

\section{KAJIAN TEORI}

\section{Bisnis}

Bisnis merupakan usaha dari seseorang atau kelompok untuk memenuhi kebutuhan hidupnya yang berkaitan dengan aktivitas produksi, pembelian dan penjualan barang atau jasa. Secara terminologi kata bisnis berasal dari bahasa inggris bussinees (Ibrahim Jones dan Sewu Lindawaty, 2007). Sedangkan bisnis secara etimologi dapat dipahami sebagai usaha seseorang atau kelompok untuk mencari laba atau keuntungan melalui aktivitas produksi atau pembelian dan penjuan produk.

Cristopher pass dkk memngemukakan bahwa adabeberapa bentuk ekonomi bisnis diantaranya: Pertama, horizontal bussiness, yaitu bisnis yang dilakukan oleh seseorang atau lebih namun hanya fokus kepada aktivitas tunggal seperti bisnis roti. Kedua, vertiacal bussines, yaitu kegiatan bisnis yang dilakukan oleh seseorang atau lebih terhadap aktivitas yang memiliki keterkaitan vertikal seperti pembuatan tepung dan roti. Conglemare atau diversified bussiness, yaitu kegiatan bisnis dengan menghubungkan 
sejumlah aktivitas produksi yang tidak berhubungan seperti bisnis tepung dan jasa keuangan.

\section{Agama}

Dalam pandangan Imam ar-Razi agama diartikan sebagai aturan-aturan tuhan yang dapat mendorong jiwa seseorang untuk mengikutinya dengan tujuan untuk mencapai dunia akhirat (Fakhruddin al-Razi, 1978). Dalam pandangan lain agama difahami sebagai sistem kepercayaan yang dianut oleh sekelompok orang sebagai doktrin atas nilai spritualitas yang tinggi. Oleh karena itu agama bagi para penganutnya adalah ajaran yang sakral (suci atau bersih) yang menjadi pedoman dalam melakukan semua aktivitasnya.

Dalam konteks Islam agama (الدين) atau yang disebut dengan ad-Din Islam bukanlah sebuah simbolis saja namun Islam yang dibawa oleh insan kamil adalah agama yang mencakup tiga unsur besar yaitu: Islam, Iman dan Ihsan. Sebagaimana hadis nabi Muhammad S.A.W

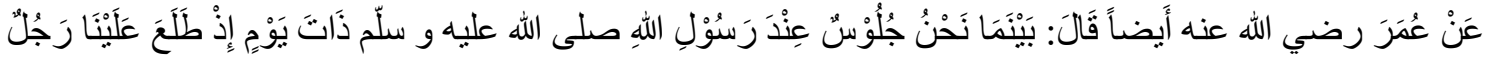

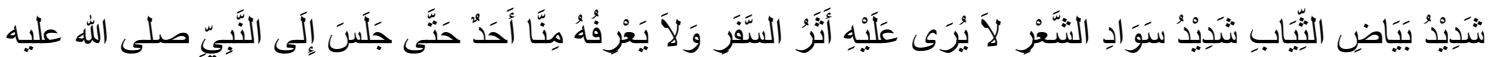

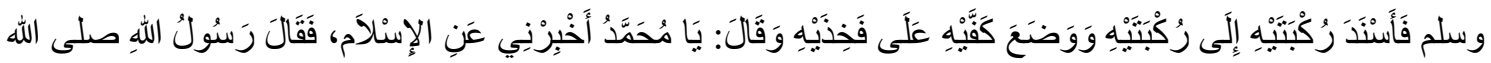

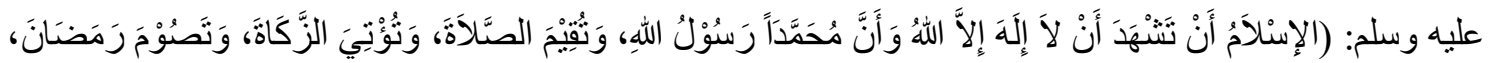

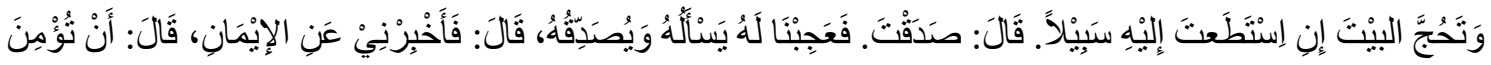

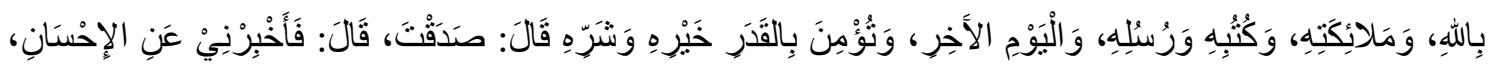

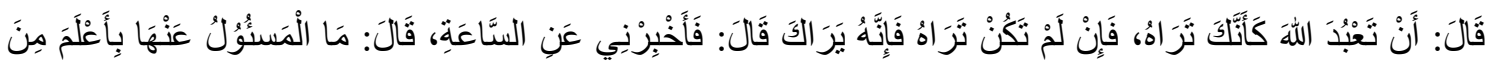

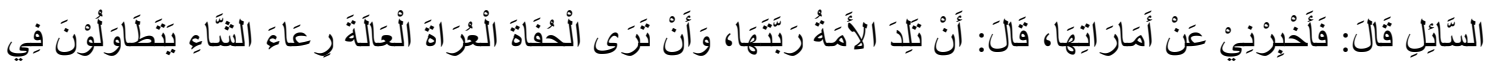

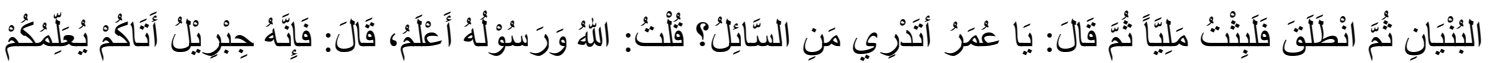

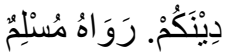

Artinya: Dari Umar ra, pula dia berkata; pada suatu hari ketika kami sedang duduk-duduk bersama Rasulullah SAW, tiba-tiba datang seorang laki-laki berpakaian sangat putih, dan rambutnya sangat hitam, tidak terlihat padanya tanda-tanda bekas perjalanan, dan tidak seorang pun dari kami yang mengenalnya, kemudian ia duduk di hadapan Nabi S.AW. dan mendekatkan lututnya lalu meletakkan kedua tangannya di atas pahanya, seraya berkata: 'Wahai Muhammad jelaskan kepadaku tentang Islam? Nabi S.AW. menjawab: ”Islam itu adalah engkau bersaksi bahwa tidak adasesembahanyang berhak disembah 
dengan benar kecuali Allah dan Muhammad adalah utusan-Nya, engkau menegakkan shalat, menunaikan zakat, puasa Ramadhan dan haji ke Baitullah Al Haram jika engkau mampu mengadakan perjalanan ke sana." Laki-laki tersebut berkata: 'Engkau benar. Maka kami pun terheran-heran padanya, dia yang bertanya dan dia sendiri yang membenarkan jawabannya. Dia berkata lagi: "Jelaskan kepadaku tentang iman? Nabi S.AW. menjawab: "Iman itu adalah Engkau beriman kepada Allah, malaikat-malaikat-Nya, kitab-kitab-Nya, rasul-rasul-Nya dan hari akhir serta engkau beriman kepada takdir baik dan buruk. ” Ia berkata: 'Engkau benar.' Kemudian laki-laki tersebut bertanya lagi: 'Jelaskan kepadaku tentang ihsan?' Beliau S.AW. bersabda: “(Ihsan adalah) Engkau beribadah kepada Allah seolah-olah engkau melihat-Nya. Kalaupun engkau tidak bisa melihat-Nya, sungguh Dia melihatmu." Dia berkata: "Beritahu kepadaku kapan terjadinya kiamat? Nabi S.AW. menjawab: "Tidaklah orang yang ditanya lebih mengetahui dari yang bertanya." Ia berkata: "Jelaskan kepadaku tanda-tandanya! Nabi S.AW. berkata: "Jika seorang budak wanita melahirkan tuannya dan jika engkau mendapati penggembala kambing yang tidak beralas kaki dan tidak pakaian saling berlomba dalam meninggikan bangunan. Umar ra berkata: 'Kemudian laki-laki itu pergi, aku pun terdiam sejenak. Maka Rasulullah S.AW. bertanya kepadaku: "Wahai 'Umar, tahukah engkau siapa orang tadi? Aku pun menjawab: "Allah dan Rasul-Nya lebih tahu." Nabi S.AW. bersabda: "Dia adalah Jibril yang datang untuk mengajarkan agama ini kepada kalian.”(H.R. Imam Muslim)

Dalam penggalah hadis diatas bahwa Agama terdiri dari tiga komponen yaitu: Islam, yaitu berserah diri kepada Allah semata dengan tunduk terhadap perintahnya semata. Iman, yaitu percaya kepada Allah, Malaikatnya, Kitab-kitabnya, para utusan Allah, hari akhir dan takdirnya Allah. Ihsan, menyembah Allah seakan-akan kita melihatnya, jika tidak melihatnya yakinlahlah bahwa Allah melihat kita. Oleh karena itu Islam merupakan agama yang sempurna yang setiap ajarannya selalu berhubungan dengan aktivitas manusia dimuka bumi, baik aktivitas, ibadah (hubungan spritualitas makluk dengan khaliqnya), aktivitas mu'amalah (hubungan sosial), politik serta urusan negara. 
Dalam bisnis nilai-nilai Islam, Iman dan Ihsan menjadi ruh bagi setiap aktivitas bisnis. Ketiganya tidak boleh dipisahkan dari aktivitas bisnis. Pertama, Islam, bahwa spirit dari aktivitas bisnis senantiasa mengandung unsur ibadah dan berserah diri kepada Allah SWT. Oleh karena itu, berbisnis akan bernilai ibadah jika dalam setiap aktivitasnya menamamkan nilai Islam. Kedua, Iman, sprit bisnis yang dilakukan selalu di kaitkan dengan keyakinan terhadap Allah SWT, bahwa kesuksesan yang diraih bukanlah hasil jerih payah pembisnis semata, akan tetapi dibalik kesuksesan seorang bisnis terdapat adalah pemberian Allah SWT. Ketiga, Ihsan, Ihsan merupakan puncak tertinggi dari perilaku sesorang, manifestasi nilai Ihsan didalam aktivitas bisnis bahwa dalam aktifvitas bahwa para aktivis bisnis senantiasa merasa diawasi oleh Allah SWT.

Pemahaman teologi kemudian diapliakasikan pada tatanan praktisi menjadi renungan bagi pelaku bisnis, bahwa bisnis yang dilakukan tidak hanya mengandung unsur duniawi saja, akan tetapi akan berdampak kepada ukhrowi (di hari ahirat kelak). Bisnis dalam pandangan agama Islam tidak hanya sebatas mencari keuntung yang sebesarbesarnya, akan tetapi ada titah ilahi yang harus di laksanakan. Orientasi bisnis didalam agama Islam tidak hanya kesenangan dunia semata akan tetapi yang menjadi orientasi bisnis adalah keuntungan dunia akhirat. Keuntungan dunia berupa hasil yang bermamfaat dan barokah dari bisnis yang dijalani, sementara keuntungan akhirat berupa nilai pahala yang diperoleh selama melakukan aktivitas bisnis didunia. Oleh karena itu, bisnis dalam pandangan agama Islam tidak hanya dipertanggung jawabkan didunia atau didepan pembisnis lainnya, akan tetapi juga akan dipertanggung jawabkan di hari kiamat kelak.

\section{Bisnis dalam Pandangan Islam.}

Islam terlahir kemuka bumi ini sebagai agama rahmatal lil 'alamin, agama yang mengatur semua aspek kehidupan manusia. Dalam pandangan Islam manusia dijadikan khalifah (pemimpin) dimuka bumi memiliki peran yang sangat urgen dibandingkan dengan makhluk Allah yang lainnya. Peran khalifah yang pertama adalah untuk menyembah Allah sementara peran kedua adalah memakmurkan alam untuk menjaga keberlangsung hidup. Untuk memenuhi keberlangsungan hidup, manusia butuh bekerja atau berbisnis.

Berbisnis merupakan perbuatan yang sangat terpuji menurut pandangan Islam. Karena yang menjadi tujuan bisnis dalam Islam tidak hanya profit oriented semata akan 
tetapi fallah oriented yaitu kebahagiana dunia akhirat. Oleh karena itu berbisnis tidak bisa dipisahkan dari nilai-nilai ibadah.

$$
\text { فاذ قضيت الصلاة فانتسرو ا فى الارض و ابتغوا من فضل الله و اذكروا الله كثير العلكم تقلحون }
$$

Artinya: Apabilah shalat telah ditunaikan maka hendaklah kalian menyebar dimuka bumi untuk mencari karunia Allah, dan ingatlah Allah sebanyak-banyaknya agar kamu menjadi orang yang beruntung (Q.S al-Jumu'ah : 10).

Dalam Islam digunakan istilah kerja seperti al- 'amal, al-kasb, al-fi'l, as-sa'yu, an-nasru, ash-sha'n, dan kemandirian (biyadihi) (Abdul Jalil, 2013). Meskipun masingmasing kata mempunyai makna dan implikasi yang berbeda, namun secara umum rententan kata-kata tersebut memiliki makna pekerjaan, berusaha dan mencari rezeki yaitu berbisnis. Setidaknya terdapat beberapa ayat al-Qur'an maupun Hadis yang dapat menjadi rujukan pesan tentang semangat kerja keras dan kemandirian bisnis, seperti:

$$
\text { قال رسول الله صلى الله عليه وسلم إن الله يحب المؤمن المحترف (احرجه البيهقى) }
$$

Sesungguhnya Allah SWT menyukai orang-orang mukmin yang berkarya.

Amal yang paling baik adalah pekerjaan yang dilakukan dengan cucuran keringatnya sendiri, 'amal ar-rajuli biyadihi (HR.Abu Dawud), dengan bahasa yang sangat simbolik ini Nabi mendorong umatnya untuk kerja keras atau berbisnis supaya memiliki kekayaan, sehingga dapat memberikan sesuatu pada orang lain.

Dalam al-Quran Allah mengatakan, Bekerjalah kamu, maka Allah dan orangorang yang beriman akan melihat pekerjaan kamu"

Artinya : Dan Katakanlah Bekerjalah kamu, Maka Allah dan Rasul-Nya serta orang-orang mukmin akan melihat pekerjaanmu itu, dan kamu akan dikembalikan kepada (Allah) yang mengetahui akan yang ghaib dan yang nyata, lalu diberitakan-Nya kepada kamu apa yang telah kamu kerjakan.

Bahkan sabda Nabi, "Sesungguhnya bekerja mencari rizki yang halal itu merupakan kewajiban setelah ibadah fardlu" (HR.Tabrani dan Baihaqi). Nash ini jelas memberikan isyarat agar manusia bekerja keras dan hidup mandiri. Bekerja keras merupakan esensi dari bisnis. Sementara itu Rasulullah SAW memberikan tuntunan bahwa salah satu cara yang paling baik dan utama untuk mencukupi kebutuhan hidup adalah lewat hasil pekerjaan dan usaha sendiri. Hal itu sebagaimana sabda nabi

$$
\text { ما أكل أحد طعاما قطُ خيرا من أن يأكل من عمل يده وإن نبي الله داود عليه السلام كان يأكل من عمل يده }
$$


Artinya: Seseorang yang makan dari hasil usahanya sendiri, itu lebih baik. Sesungguhnya Nabi Daud as makan dari hasil usahanya sendiri.

Dalam sejarahnya Nabi Muhammad, istrinya dan sebagian besar sahabatnya adalah para pembisnis mancanegara yang piawai. Beliau adalah praktisi bisnis dan sosok tauladan bagi umat. Oleh karena itu, sebenarnya tidaklah asing jika dikatakan bahwa mental entrepreneurship inheren dengan jiwa umat Islam itu sendiri. Bukanlah Islam adalah agama kaum pedagang, disebarkan ke seluruh dunia setidaknya sampai abad ke $13 \mathrm{M}$, oleh para pedagang muslim.

Dari aktivitas perdagangan yang dilakukan, Nabi dan sebagian besar sahabat telah mengubah pandangan dunia bahwa kemuliaan seseorang bukan terletak pada kebangsawanan darah, tidak pula pada jabatan yang tinggi, atau uang yang banyak, melainkan pada pekerjaan. Ustman bin Affan dengan bisnis dagangannya (bahan pakian) membesar hingga menjadi sebuah konglomerasi uasaha yang membawa banyak kebaikan bagi umat islam di Madinah. Imam Abu Hanifah, selain sibuk mengurus umat dan menjaga syari'at beliau juga seorang pembisnis bahan pakaian yang amat jujur dan berhasil (M.I. Yusanto dan M.K. Widjajakusuma, 2002).

\section{Prinsip-Prinsip Bisnis dalam Islam.}

Secara garis besar ada dua prinsip besar bisnis dalam Islam yaitu prinsip umum dan prinsip khusus. Prinsip umum dari bisnis syari'ah adalah:

Pertama, Prinsip Illahiyah, prinsip ini adalah prinsip yang utama didalam bisnis Islam, prinsip illaahiyah didasarkan pada nilai-nilai ketuhanan yang menjadi pemandu terhadap aktivitas bisnis. Oleh karena itu yang menjadi orientasi bisnis pada prinsip illahiyyah bukan hanya laba semata yang bersifat material akan tetapi keberkahan dari sebuah bisnis dengan segala bentuk kebaikan-kebaikan. Aspek illahiyah akan melahirkan prinsip bahwa tanggung jawab didalam besnis tidak hanya bersifat horizontal (tanggung jawab kepada sesama manusi) akan tetapi tangnggung jawab yang bersifat vertikal (tanggung jawab kepada Allah).

Kedua, Prinsip Nubuwwah, yaitu prinsip bisnis yang disandarkan kepada sifat kenabian. Dalam hal bisnis nabi Muhammad SAW tidak hanya memberikan serentetan aturan bisnis secara lisan saja, akan tetapi nabi Muhammad memberikan contoh teladan dalam hal bisnis. Prinsip an-Nubuwah ini tercermin pada sifat kenabian yaitu STAF (Siddiq, Tabligh, Amanah dan Fatahanah). Siddiq artinya jujur, dalam hal bisnis Islam 
kejujuran menjadi syarat utama untuk mencapai keberhasilan bisnis. sedang amanah (kredibel) nilai amanah telah tercermin pada praktek bisnis nabi dengan Syaidah Siti Khadijah, Syaidah Khadijah merasa aman terhadap modal yang berupa Financial assets sementara nabi memiliki modal berupa skill asset, hal ini dikarenakan nabi memiliki prinsip amanah sehingga patner bisnis nabi tidak merasa khawatir terhadap financial nay. Tabligh berati komunikatif transparansi, prinsip ini telah dipraktikkan oleh nabi muhammad saat menjalani bsnis dengan sayyidah Khadijah, nabi melaporkan secara tranparansi atas hasil yang diperoleh dari bisnis yang telah dijalankan. Fathonah, pada prinsip ini akan melahirkan initiativ (inisiatif) kepada mitra kerjanya, dalam hal ini seorang pembisnis akan menimbulkan sifat dinamis dan tidak stanan.

Ketiga, Prinsip al-Adaliyyah, prinsip ini merupakan setral terhadap pengelolaan bisnis dalam pandangan Islam. Oleh karena itu prinsip keadilan harus masuk dalam sendisendi pengelola bisnis. Tujuan dari prinsip keadilan adalah untuk mendatangkan kemaslahatan secara umum, baik pelaku bisnis atau para konsumen.

Keempat, Prinsip al-Hurriyah, pada prinsip ini pelaku bisnis diberikan kebebsan untuk berkreasi serta membangun kreativitas bisnis sesuai dengan kepiawaiannya. Namun kebebasan tersebut tetap memperhatikan rambu-rambu syari'at Islam. Kelima, Prinsip al-Musawwah, prinsip ini akan menciptakan iklim kemitraan yang baik diatara pelaku bisnis, dengan prinsip kesetaraan hubungan dalam bisnis akan terjalin indah. Keenam, Prinsip Ta'awun, prinsip ini adalah prinsip persaudaraan, dalam diri pembisnis tertanam nilai saling tolong menolong, oleh karena itu yang menjadi dasar daam bisnis Islam adalah rasa saling tolong menolong.

\section{KESIMPULAN}

Bisnis dalam pandangan Islam merupakan keharusan bagi manusia dalam rangka untuk memenuhi kebutuhan hidupnya. Islam tidak melarang manusia untuk melakukan bisnis, jauh dari pada itu Islam memberikan rambu-rambu atau prinsip-prinsip dalam berbisnis. Aktivitas-aktivitas bisnis dalam pandangan agama Islam senantiasa menerapkan nilai-nilai Ismal, Iman dan Ihsan. Prinsip-prinsip bisnis dalam Islam Prinsip Illahiyah, Prinsip Nubuwwah, Prinsip al-Adaliyyah, Prinsip al-Hurriyah, Prinsip alMusawwah, Prinsip Ta'awun. Islam bukanlah agama yang melarang bisnis, akan tetapi Islam adalah agama yang mendukung kegiatan bisnis. 


\section{Daftar Pustaka}

Eko Suprayitno. (2005). Ekonomi Islam, Pendekatan Ekonomi Makro Islam dan Konvensional. Yogyakarta: Graha Ilmu.

Abdul Jalil. (2013). Spritual Enterpreneurship Transformasi Spritualitas Kewirausahaan. Yogyakarta: Lkis.

Dr. Francis Tantri. (2009). Pengantar Bisnis. Jakarta: Rajawali Pers.

Fakhruddin al-Razi. (1978). Mafatih al-Ghayb XIX. Beirut : Dar al-Fikr.

Ibrahim Jones dan Sewu Lindawaty. (2007). Hukum Bisnis Dalam Persepsi Manusia Modern. Bandung : PT. Radika Aditama.

M.I. Yusanto dan M.K. Widjajakusuma. (2002). Menggagas Bisnis Islam . Jakarta: Gema Insani Press. 